\title{
SECTORAL VARIATIONS ON TECHNINAL EFFICIENCY AND RETURN TO SCALE IN THE INDONESIAN ECONOMY
}

\author{
Muchdie \\ Muhammadiyah Universityof Prof. DR. HAMKA, Jakarta \\ eidmuchdie@uhamka.ac.id
}

\begin{abstract}
This paper discusses on sectoral variations of technical effciency and return to scale in the Indonesian economy. Employing regression analysis of Cobb-Douglas production function, thesecoefficientswere calculated. Nine economic sectors in the Indonesian economy: Agriculture, Mining and Quarying, Manufacturing, Electricity,Gas and Drinking Water, Construction, Trade, Hotel and Restaurant, Transportation and Communication, Finance, Rental and Corporate Services, and Services, were exercised to study the variation of those coefficiens. Sectoral data on gross domestic product, capital stock and employment are those from the years 1967 to 2007 collected from many documents available at the National Statistics Agency. The result shows that the coeffiecients of technical efficiency do vary among sectors. Those sectors in which the coefficients were above that at the national level, experienced decreasing return to scale. On the contrary, those sectors in which the coeffiecients were below that at national level, experienced increasing return to scale.
\end{abstract}

Keywords: Sectoral variation, technical efficiency, returns to scale.

\begin{abstract}
Abstrak
Paper ini membahas keragaman sektoral dari koefisien efisiensi teknis dan skala hasil dalam perekonomian Indonesia. Menggunakan analisis regressi terhadap fungsi produksi CobbDouglas, koefisien-koefisien tersebut telah dihitung. Ada sembilan sektor dalam perekonomian Indonesia dalam kajian ini, meliputi : Pertanian, Pertambangan dan Galian, Industri, Listrik, Gas dan Air Minum, Konstruksi, Perdagangan, Hotel dan Restoran, Angkutan dan Komunikasi, Jasa Keuangan Persewaandan Perusahaan, dan Jasa-jasa. Data produk domestic bruto dan cadangan modal atas harga konstan tahun 2000 serta tenaga kerja dari setiap sector untuk tahun 1967 sampai 2007 diambil dari berbagai terbitan Badan Pusat Statistik. Hasil analisis menunjukkan bahwater dapat keragaman dalam hal koefisien effisiensi teknis dan skala hasil berdasarkan sektor. Sektor-sektor dengan koefisien efisiensi teknis di atas rata-rata nasional mengalami skala hasil yang menurun. Sebaliknya, sektor-sektor dengan koefisien efisiensi teknisnya di bawah rata-rata nasional mengalami skala hasil yang meningkat.
\end{abstract}

Kata kunci : Keragaman sektoral, efisiensi teknis, skala hasil.

Received: May 10, 2016; Revised: August 20, 2016; Approved: September 5, 2016 


\section{INTRODUCTION}

Since it has been declared its independence on 17 August 1945, the Indonesian economy has been up and down, experiencing booming and recession (Anonymous, 1998, 2004, 2010). Economic cyclesuch as booming, recession, and even crisis do exist in Indonesian economy. Economists have long recognised that technology is a factor of production, and even the most importan factor, given its role in labor quality and the design of capital good. Technological advances play a crucial role in improving productivity and thus the standar of living of a system; economic system (Adams. 2006).

Most economists today agree with the hypotesis that both innovation and technological spilovers are the main engine for explaining productivity growth. Neoclassical economists tend to give all sectors of the economy equal weight for explaining productivity behavior, but structuralist economists argue that manufacturing sector is the main force for explaining the aggregate productivity. Although economic development is basically determined by technical progress, the productive structure of developed economies continues to be much more complex and diversified than that of developing economies. It means that economic development can be understood as a process through which a deep structural change occurs in the economy, in such a way that there is a reallocation of resources from primary sectors (agriculture and mining) to the manufacturing sector, and then as soon as an economy has achieved high level of income per capita, from manufacturing to service sector (Nassif \& Feijo, 2013).

Measuring the effect of technology on productivity is a difficult pursuit. It is generally approached through metrics such as Gross Domestic Product, GDP per capita and Total Factor Productivity (TFP). The former two attempt to capture the overall output of a given economy from a macro-environmental perspective. The latter is attempting to measure technologically driven advancement through noting increase in overall output without increases in input. This is done through utilising production function equations and identifying when the output is greater than the supposed input, implying an advance in external technological environment(Boundless, 2016). The technology can be regarded as primary resource in economic development. The level of technology is also an important determinant of economic growth. The rapid rate of growth can be achieved through high level of technology. It was observed that 
innovation or technological progress is the only determinant of economic progress. But if the level of technology becomes constant the process of growth will stops. Thus, it is the technological progress which keeps the economy moving. Inventions and innovations have been largerly responsible for rapid economic growth in developed countries (Debasish, 2016).

In economics, the Cobb-Douglas production function is widely used to represent the relationship of an output to input (Bao Hong, 2008). It was proposed by Knut Wicksell $(185 \mathrm{I}-1926)$ and tested againts statistical evident by Charles Cobb and Paul Douglas in 1928 (Cobb and Douglas, 1928). From Cobb-Douglas production function, technical efficiency aslo known as total factor productivity, retun to scale, and ouput-capital elasticity as well as output-labor elasticity can easily be calculated by employing regression analysis (Salvator, 1996).

Previous research on technical efficiency, return to scale and output elasticities has been conducted, among others byBiresh K. Sahoo, at all (2014), V. E. Krivonozhko,A. V. Dvorkovich,O. B. Utkin, I. D. Zharkov, M. V. Patrin and A. V. Lyche (2007), Tewodros G. Gebreselasie (2008), Feng, G and Serletis, A (2010), Holyk, S. (20I6), Page, John M. Jr (1980),Erkoc, T. E., (20I2), Yudistira, D (2004). Measuring Indonesia's sectoral effieciencies has been conducted by Rizaldi Akbar (20I5).

Structural transformation process in the Indonesian economy is indicated initially by the dominance of agricultral sector both in output and in employment. The primary sector, namely: Agriculture and Mining-Quarying dominated the Indonesian economy until 1987-1988, but Secondary (Manufacturing) and Tertiary Sectors (Trade, Hotel and Restaurant) have replaced this position after 1999 in term of output. But, in term of employment, data show that during the year of 1967 to 2007, Agriculture has still dominated the Indonesian economy. The reseach reported in this paper aimed to analyzed the sectoral variations of the coefficients of technical efficiency, return to scale and output-capital elasticity as well as outputlabor elasticity in the Indonesia economy during the year of 1967 to 2007. 


\section{METHODS}

Cobb-Douglas production function, $Q=\gamma K^{\alpha} L^{\beta}$, was employed in this exercise to calculate technical efficiency $(\gamma)$ return to scale $(\alpha+\beta)$, output-capital elasticity $(\alpha)$ and output-labor elasticity $(\beta)$. This production function was developed and statistically tester by Charles Cobb and Paul Douglas during 1927-1947 (Cobb C.W, and Douglas, P.H., 1928), where: $\mathrm{Q}=$ total production (the real value of all good and services produced in a year; $\mathrm{K}=$ capital input (the real value of all machinery, equipment, and building; $\mathrm{L}=$ labor input (the total number of person-hours worked in a year; $\gamma=$ technical efficiency in production process, known as total factor productivity; $\alpha=$ output-capital elasticity; $\beta=$ output-labor elasticity.

Technical efficiency $(\gamma)$, or total factor productivity (TFP) is the portion of output not explained by the amount of input used in production (Comin, 2006). This is a method of measuring overall productivity of business, industries or economies. Technical efficiency is the effectiveness with which a given set inputs is used to produced an output. A firm or an economy is said to be technically efficient if a firm or an economy is producing the maximum output from the minimum quantity of inputs, such as labor, capital and technoloy. Technical efficiency is related to productive efficiency wich is concern with producing at the lowest point on the short run averaga cost curve. Thus productive effiency required technical efficiency (Pettinger, 2012).

The values of $\alpha$ and $\beta$ are basically determined by available technology. Output elasticity measure the responsiveness of output to a change in levels either capital or labor used in production. Further more, if $\alpha+\beta=1$, the production function has constant return to scale, meaning that doubling the usage of capital (K) and labor (L) will also double output (Q).If $\alpha+\beta<1$, return to scale are decreasing and if $\alpha+\beta>1$, return to scale are increasing.

The output elasticity of capital, $E_{K}=\delta Q / \delta K . K / Q=\alpha Q / K . K / Q=\alpha$. Similarly, the output elasticity of labor, $E_{L}=\delta Q / \delta L . L / Q=\beta Q / L . L / Q=\beta$ and $E_{K}+E_{L}=\alpha+\beta=$ return to scale (Salvator, D., 1996).Converting the production function from $Q=\gamma K^{\alpha}$ $L^{\beta}$ in to a logarithms form that is, $\ln Q=\ln \gamma+\alpha \ln K+\beta \ln L$. As this is a linier form, then the coefficiens $(\gamma, \alpha$ and $\beta$ ) can easily be estimated by regression analysis (Gasperz, 1996). 
The Cobb-Douglas production function can be estimated either from data for a single firm, industry, region or nation over time using time-series analysis or for a single firm, industry, region or national one point in time using cross-sectional data(Salvator, 1996). Data needed for this exercise were sectoral data on Gross Domestic Product, Capital Stock and Employment. Yearly data on GDP, Capital Stock and Employment were collected from the Central Beurau of Statictics. Fortunately data were available from the year of 1967-2007.

\section{RESULT AND DISCUSSION}

\section{Sectoral GDP, Capital Stock and Employment}

Figure I provides data on GDP (Gross Domestic Product in Billion Rupiah) in the Indonesia economy during 1967 to 2007. In 1967, the GDP in 1967, the early year of Suharto rezim, was Rp417.76 Billion and GDP at the last year (2007) was Rp. 2,686.49 Billion. On average, Indonesian GDP during 30 years grows at $5.11 \%$. It was noted, however, that when multi-dimensionaleconomic crisis (known as monetary crisis or IMF crisis) occurred in 1998, the Indonesian GDP grows at negative (-13.13\%), from Rp. I,555.32 Billion in 1997 to Rp. I,35 I.I6 Billion in 1998.

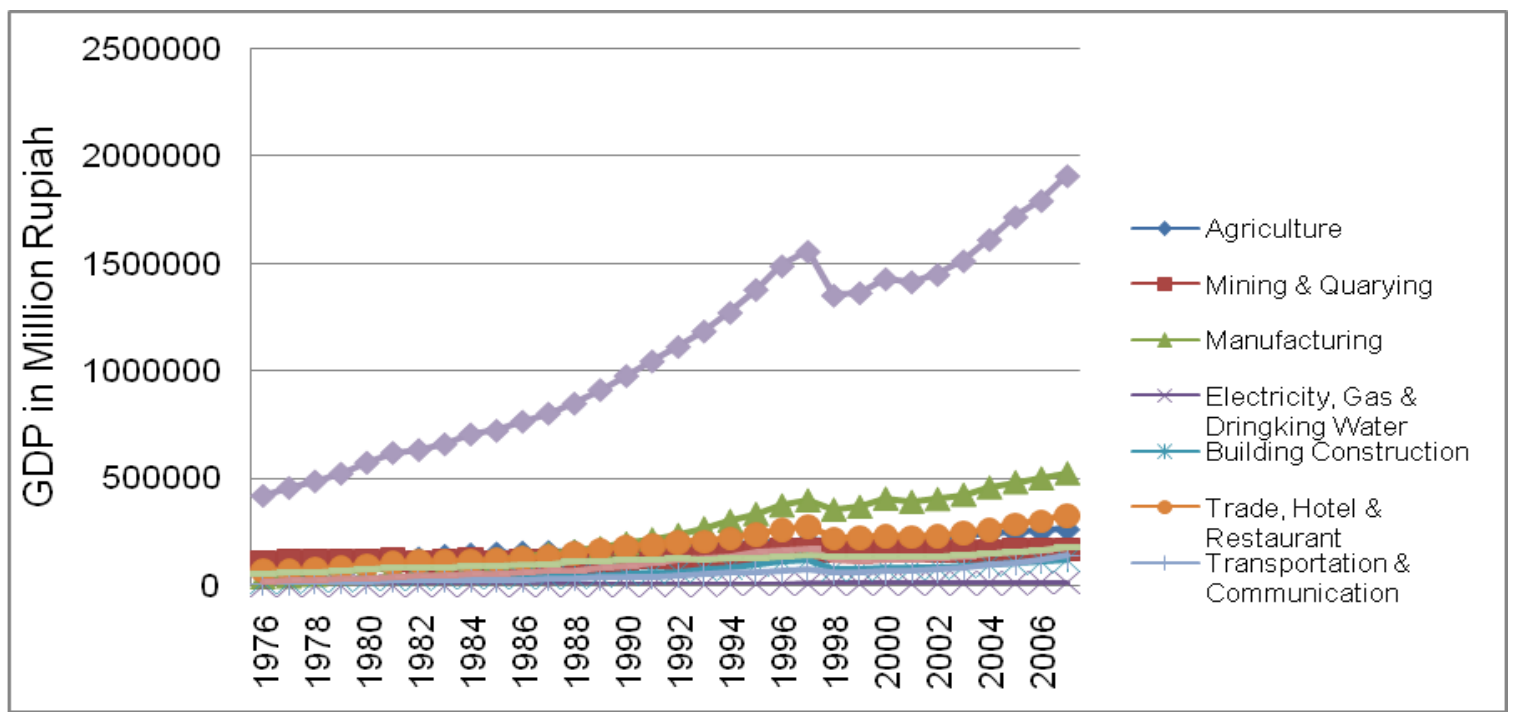

Figure I. Gross Domestic Product in the Indonesian Economy

Figure 2 provides sectoral GDP in more detail. In 1967, sectoral GDP were dominated by Mining and Quarying (Rp. 105,076 Million) and Agriculture (Rp. 99,642 Million), followed by Trade, Hotel and Restaurant (Rp. 7I,I04 Million), Services (Rp. 5I,468 Million), Manufacturing (Rp. 40,359 Million), Financial, Rental and Corporate 
Services (Rp.20,212 Million), Building Construction (Rp. 16,794 Million), Transportation and Communication (Rp. 12,490 Million) and Electricity, Gas and Drinking Water (Rp. 617 Million). At the year of 2007, sectoral GDP was dominated by Manufacturing (secondary industry) with GDP of Rp. 522,65I Million and followed by Trade, Hotel and Restaurant (Rp. 329,228 Million), Agriculture (Rp. 263,800 Million), Financial, Rental and Corporate Services (Rp. 178,394 Million), Services (Rp. 176,755 Million), Mining and Quarying (Rp. 166,449 Million), Transportation and Communication (Rp. 138,846 Million), Building and Construction (Rp. I 8,406 Million), and Electricity, Gas and Drinking Water (Rp. 13, I37 Million).

Agriculture GDP grows in average $3.21 \%$, with the lowest growth of $0.03 \%$ in the year of 1967 and $0.51 \%$ in the year of 2000 , and the highest growth of $8.39 \%$ in the year of 1982 and $8.37 \%$ in the year of 1968. No negatice growth experienced by the sector, even in the time when multidimension of economic crisis in the 1998.Mining and Quarying GDP grows in average I.63\%. This sector experienced many negative growth for instance in the years of 1981 (-10.78\%), $1984(-10.22 \%), 1987(-5.71 \%)$, I99I (-2.45\%), 1997 (-0.50\%), 1998 (-2.57\%), 2000 (-3.7I\%), 200 I (-0.99\%), 2002 (I.72\%), and 2003 (3.08\%).

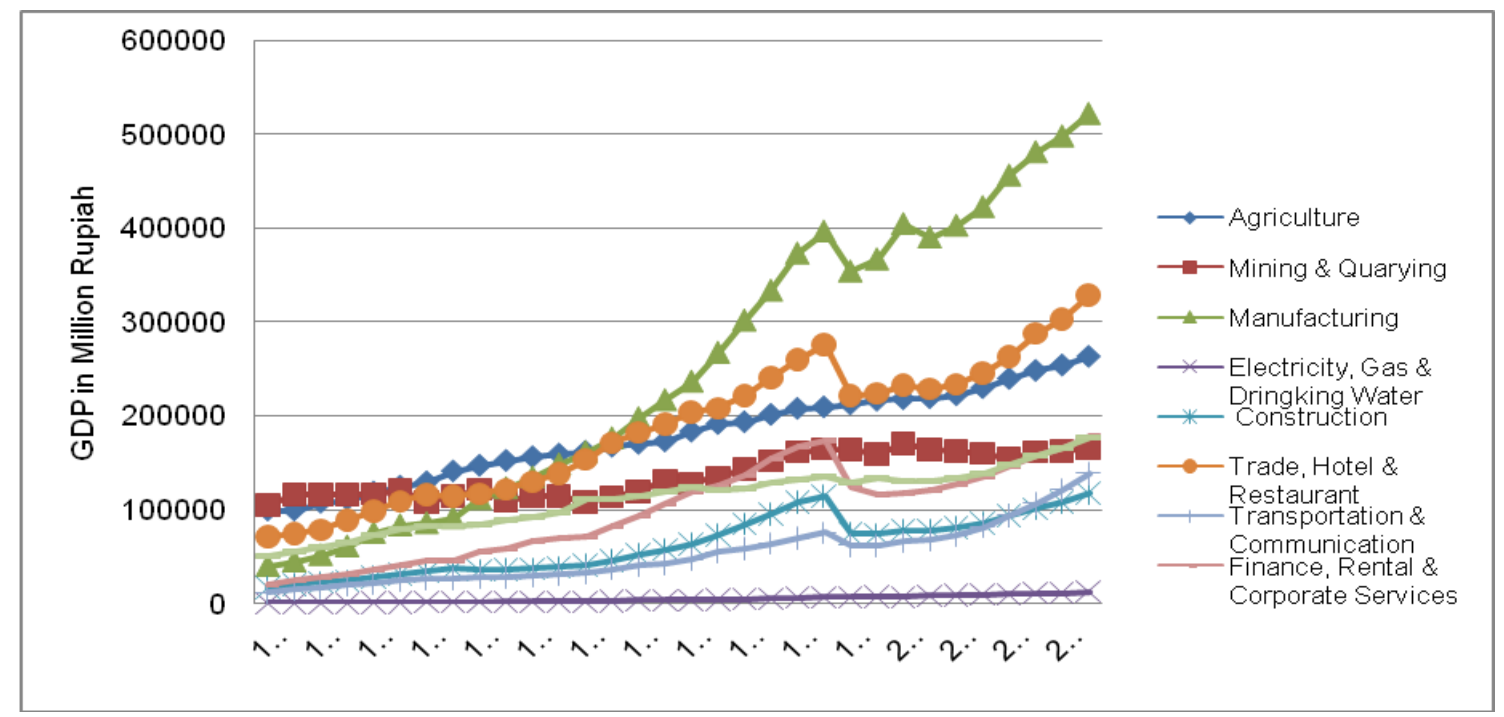

Figure 2. Sectoral Gross Domestic Product in the Indonesia Economy

Manufacturing GDP grows in average $8.81 \%$ thesecond highest growth in the Indonesian economy during 30 years period. The highest growth occurred in the year of 1979, still in Oil Boom phase, as 23.92\%, as well as in 1983 (22.19\%). Some negative growth occurred in the year of 1997, early year of monetary crisis $(-10.73 \%)$, and the 
year of 2000 (-3.55\%).GDP of Electricity, Gas and Drinking Water sector growth in average at $10.67 \%$ the highest sectoral GDP growth in Indonesia economy. This sector has the smallest value of GDP among sectors in the Indonesia economy during the period of 30 years. The highest GDP growth of this sector was $31.99 \%$ occurred in 1978, in the period of OilBoom. In 1999, this sector experienced negative economic growth, $11.70 \%$.

GDP of Construction sector grows in average at $7 \%$ with the highest growth (18.87\%) occurred in 1967. This sector experienced with negative GDP growth three time, namely in 1983 (-4.32\%), 1997 (-34.67\%) and 1998 (-0.95\%). Monetary crisis hadvery significant impact on construction sector.In average, the sector of Trade, Hotel and Restaurant grows at 5.24\%, the 6th rank in the growth of sectoral GDP. The highest growth occurred in the years of 1978 (12.60\%), 1979(10.90\%, 1980 (10.66\%), 1987 (10.55\%) and 1988 (II.64\%). Negative growth of GDP occurred in the years of 1982 (-I.06\%), 1997 (-9.70\%) and 2000 (-I.86\%).

Transportation and Communication sector grows in average at $8.32 \%$, the third highest sectoral growth in the Indonesian economy during 1967 to 2007 . The highest growth occurred in the years of 1976 (22.99\%) and 1978 (17.08\%). Negative growth occurred in the year of 1997 (-17.86\%). The sector of Financial, Rental and Corporate Services grows in average at 7.7\%, with the highest growth occurred in 1976 (26.91\%). Negative GDP growth of this sector occurred in years of 1997 (-28.48\%) and 1998 ($6.42 \%)$, the years when monetary crisis exist. The services sector grows in average at 4. I4\% which was the highest growth occurred in the year of 1987 (15.10\%). Negative growth of this sector occurred in the year of $1982(-0.05 \%), 1988(-0.50 \%), 1992(-$ I.97\%), 1997 (-5.10\%), and $1999(-2.44 \%)$.

Figure 3 presents sectoral capital stock in the Indonesian economy 1967-2007. In 1967, sectoral capital stock were dominated by Manufacturing (Rp. 22,070 Million), followed by Mining and Quarying (Rp. 20,730 Million), Services (Rp. 15,740 Million), Transportation and Communication (Rp. 12,640 Million), Financial, Rental and Corporate Services (Rp. 8, 120 Million), Trade, Hotel and Restaurant (Rp.7,770 Million), Construction (Rp. 6,450 Million), Agriculture (Rp. 4,550 Million) and Electricity, Gas and Drinking Water (Rp. I,940 Million). At the year of 2007, 30 years later, sectoral capital stock was dominated by Services (Rp. 28,770 Million) and followed by Financial, 
Rental and Corporate Services (Rp. 17,010 Million), Transportation and Communication (Rp. 14,420 Million), Trade, Hotel and Restaurant (Rp. I2,750 Million), Manufacturing (Rp. 10,950 Million), Electricity, Gas and Drinking Water (Rp. 7,820 Million), Agriculture (Rp. 4.5I0 Million), Mining and Quarying (Rp. 2,770 Million), and Construction (Rp. I, 190 Million).

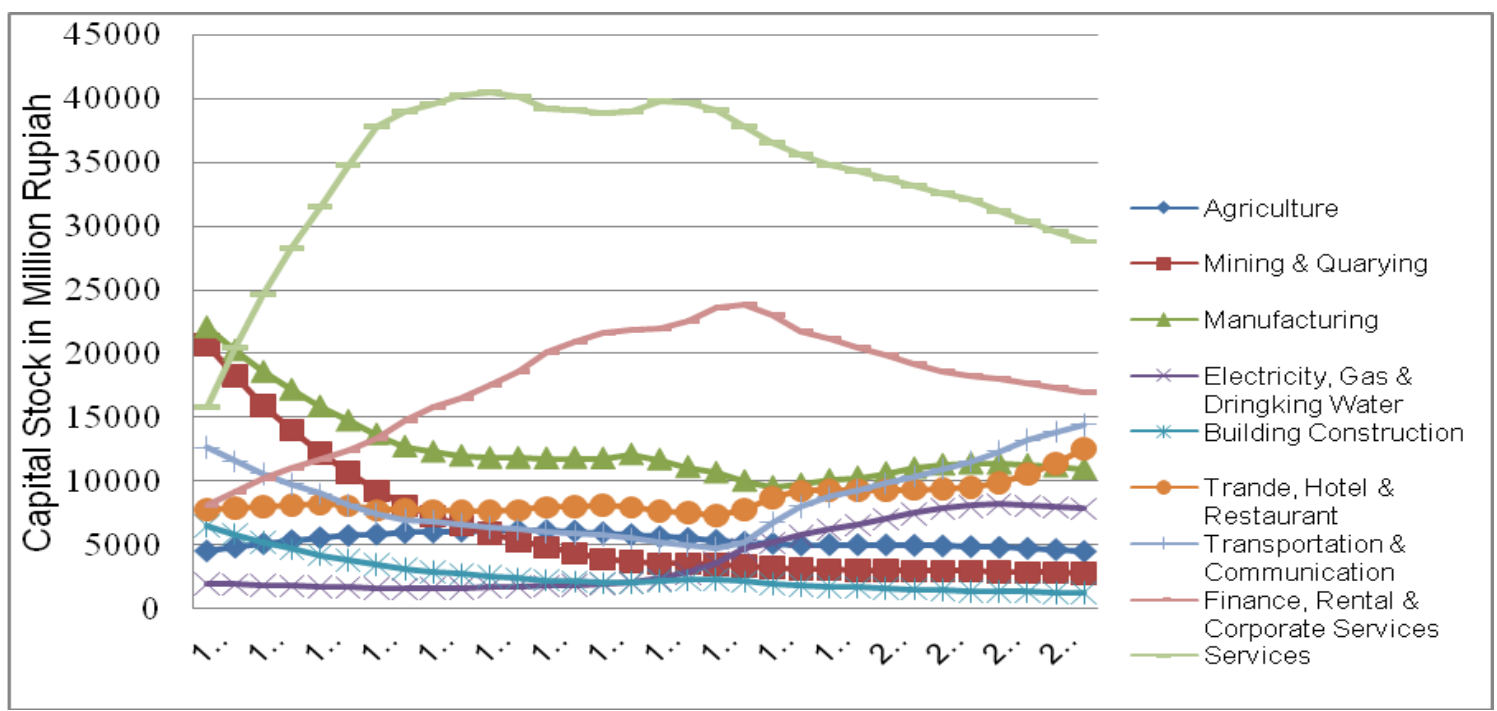

Figure 3. Capital Stock in the Indonesia Economy

Agriculture capital stock grows in average at $0.00 \%$, with the highest growth of $6.59 \%$ in the year of 1967 . The growth of this sector continually declaine afterward and the growth expereienced negative after the year 1987. Only in the year 1997 and 1998 the growth back to positive growth. After the year of 1998, negative growth occured. Mining and Quarying capital stock experienced negative growth. In average, this sector grows in average at $-6.16 \%$. From 30 years period, only 2 years in which this sector had a positive growth in capital stock, namely year : $1992(0.85 \%)$ and $200 \mathrm{I}(0.00 \%)$. Manufacturing capital stock also grows in average at $-2.16 \%$. The lowest growth (mean the highest negative growth) occured in the year 1976 (-8.25\%). More than a half of the 30 years period experinced negative growth.

There are some more year, though, with positive growth such as : the year of 1988 (0.25\%), 1990 (2.63\%), 1996 (2.09\%), 1997 (3.49\%), 1998 (2.08\%), 1999 (3.20\%), 2000 (3.57\%), $200 \mathrm{I}$ (2.45\%), and 2002 (0.89\%). Capital stock of Electricity, Gas and Drinking Water sector growth in average at $4.93 \%$ the highest sectoral capital stock growth in Indonesian economy during 1967-2007. The highest capital stock growth of this sector was $29.69 \%$ occurred in 1994 . Negative growth experienced by this sector 
were in 1976 to 1982 and during 2004 to 2007. Capital stock of Construction sector grows in average at negative growth $(-5.23 \%)$. Almost the whole year experienced negative growth, expect in the year of 1990 (3.03\%), 1991 (3.43\%), 1992 (4.27\%) and 1993 (I.82\%). In average, capital stock ofHotel and Restaurant grows only at 1.63\%). The highest growth occurred in the years of 1995 (12.10\%). Negative growth of capital stock of this sector occurred in sveral years, namely: the years of 1980 (-1.46\%) 198I($4.20 \%), 1983$ (-0.64\%), 1984 (-0.52\%), 1985 (-0.78\%), 1990 (-2.09\%), 199। (-3.38\%), $1992(-1.82 \%)$ and $1993(-3.43 \%)$.

Transportation and Communication sector grows in average at $0.78 \%$. The highest growth occurred in the years of 1995 (29.17\%). More than a half of the study period were negative in growth of capital stock, that was the period of year 1967 to 1994. After 1995, the growth of capital stock of this sector were positive. The sector of Financial, Rental and Corporate Services grows in average at $2.54 \%$, with the highest growth occurred in 1976 (13.18\%). Positive growth occured during 1967 to 1994. Meanwhilenegative capital stock growth of this sector occurred during the year 1995 to 2007.

The services sector grows in average at $2.20 \%$ which was the highest growth occurred in the year of 1967 (29.48\%). Positive growth of this sector occurred during the year 1967 to 1985 and during 1990 to 199I. Negative growth occurred during 1986 to 1989 and during the year of 1992 to 2007.

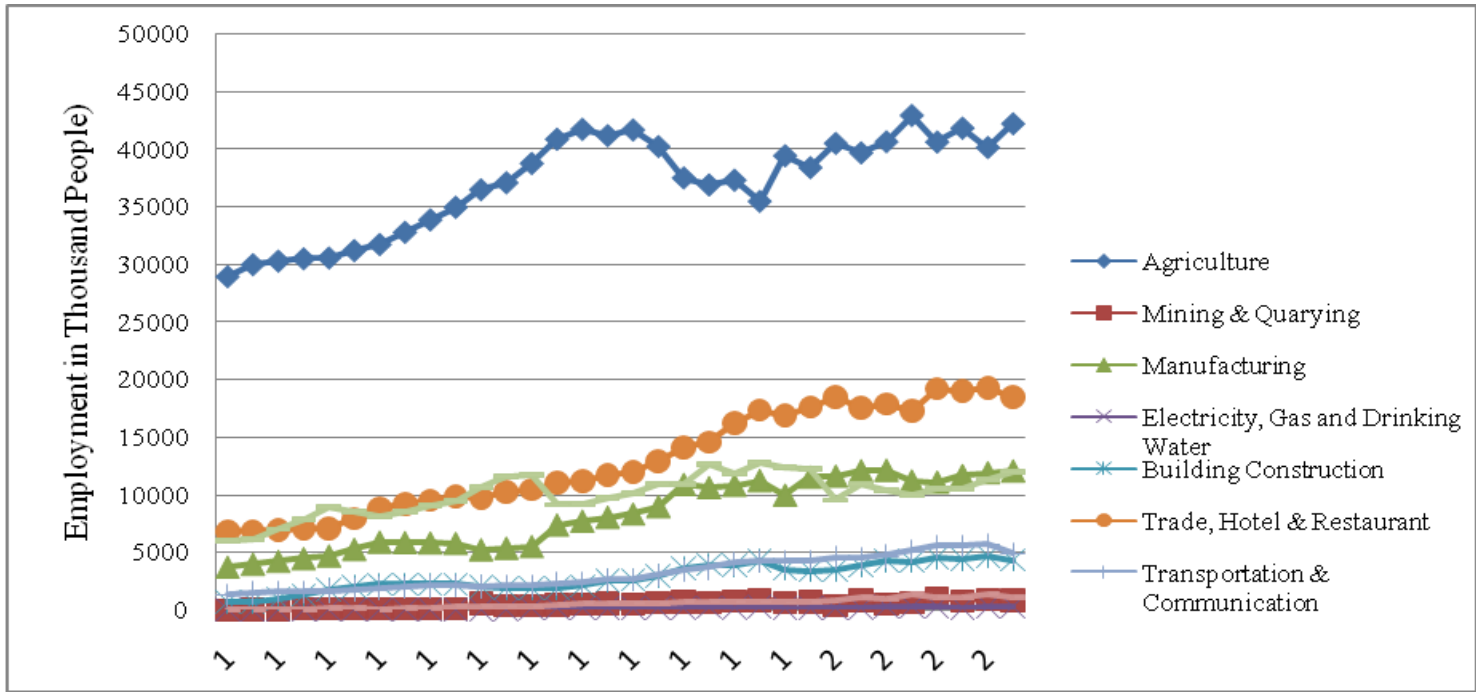

Figure 4. Employment in the Indonesia Economy (1967-2007)

From Figure 4, it is clearly shown that Agriculture has dominated the Indonesia economy in term of employment. It was then followed by Trade, Hotel and 
Restaurant. In 1967, employment in Agriculture sector was 28,879 thousand people. Employment in Trade, Hotel and Restaurant was 6,773 thousand people. In 2007, people work in Agriculture sector was 42,200 thousand, and in Trade, Hotel and Restaurant was $|8,44|$ thousand.

In term of growth in employment, the highest growth was Mining and Quarying (average at $21.08 \%$ ), followed by Financial, Rental and Corporate Service (average at I8.8I\%), Electricity, Gas and Drinking Water (average at II.57\%), Construction (average at 7.01\%), Transportation and Communication (4.50\%), Manufacturing (4.24\%), Trade, Hotel and Restaurant (3.39\%), Services (2.69\%) and Agriculture (I.30\%). All sectors experienced with positive and negative growth.

\section{Discussion}

Tabel I shows the coefficients of technical efficiency $(\gamma)$ return to scale $(\alpha+\beta)$, output-capital elasticity $(\alpha)$, and output-labor elasticity $(\beta)$ in the Indonesian economy during 1967 to 2007 both at national level and sectoral level.

Tabel 1. Coefisiens of Technical Efficiency, Return to Scale, and Ouput Elasticities

\begin{tabular}{lcccc}
\hline Sectoral Analysis & $\gamma$ & $\alpha$ & $\beta$ & RTS \\
\hline National Average & 2.775174 & 0.797882 & -0.016258 & 0.781624 \\
Agriculture & -0.687019 & -0.790724 & 1.987609 & 1.196886 \\
Mining and Quarrying & 5.298335 & -0.219114 & -0.007185 & -0.226299 \\
Manufacturing & 4.313086 & -0.865074 & 1.536815 & 0.671741 \\
Electricity GasDrinking Water & 12.040516 & 2.353230 & -2.691094 & -0.337864 \\
Construction & 4.910134 & -1.159027 & 0.022766 & -1.136262 \\
Trade, Hotel \& Restaurant & 2.487391 & -0.214749 & 1.246332 & 1.031584 \\
Transportation \& Communication & 2.717723 & -0.157543 & 1.344240 & 1.186697 \\
Financial, Rental \& Coorp Services & -1.470291 & 2.236066 & -0.102564 & 2.133502 \\
Services & 1.925433 & -0.214449 & 1.530741 & 1.316292 \\
\hline
\end{tabular}

Technical effiency in Indonesian economy during the year 1967 to 2007 was

2.775 I74. At sectoral perspective the coefficients of technical efficiency vary among sectors. From 9 economic sectors, 4 sectors had coeffient of thechnical efficiency which were above of that at national level, and other 5 sectors were below that at the national level. The sectors which the coefficient of technical efficiency above of that at national level were : Electricity, Gas and Drinking Water (12.040516), Mining and Quarying (5.298335), Construction (4.910134), and Manufacturing (4.313086). The sectors which the coefficient of technical efficiency below of that at national level were 
: Financial, Rental and Corporate Services (-I.47029I), Agriculture (-0.687019), Services (1.925433), Trade, Hotel and Restaurant (2.48739I) and Transportation and Communication (2.717723). It means that the technical effiency of 4 sectors earlier were better than that at the national level. Meanwhile the technical efficiency of 5 other sector were worse than that at the national level. These 5 sectors should have get more attention by policy makers, especially those that the values of the coeffient were negative.

At national level, Indonesian economy experienced decreasing return to scale as the coeffient of return to scale which is the summation of coefficient of outputcapital elasticity $(\alpha)$ with coefficient of output-labor elasticity $(\beta)$ less than unity (0.781624). The coeffients of return to scale vary among sectors, where 5 sectors were increasing return to scale and 4 sectors were decreasing return to scale. Five increasing return to scale sectors were : Financial, Rental and Corporate Services (2.133502), Services (1.316292), Agriculture (1.196886), Transportation and Communication (I.186697), and Trade, Hotel and Restaurant (I.031584). These 5 sectors experiencing increasing return to scale were the sectors in which their coeffients of technical efficiency were below of that at the national level. Four decreasing return to scale sectors were : Manufacturing (0.67174I), Mining and Quarying (-0.226299), Electricity, Gas, and Drinking Water (-0.337864), and Construction (-I.136262). Again, those sectors that had the coefficient of technical efficiency above that at national level experiencing decreasing return to scale.

The coefficients of output-capital elasticity $(\alpha)$ in the Indonesian economy was 0.797882 . Sectoral coeffient of output-capital elasticity vary among sectors. Only two sectors in which coefficient of output-capital elasticity above that of the national average, namely :Electricity, Gas and Drinking Water (2.353230) and Financial, Rental and Corporate Services (2.236066). Seven sectors with the coefficients of outputcapital elasticity below that at the national level, namely : Agriculture (-0.790724), Mining and Quarying (-0.219114), Manufacturing (-0.865074), Construction (I.159027), Trade, Hotel and Restaurant (-0.214749), Transportation and Communication (-0.157543) and Services (-0.214449).

The coefficients of output-labor elasticity $(\beta)$ in the Indonesian economy was 0.016258 . Sectoral coeffient of output-labor elasticity vary among sectors. There were 
five sectors in which coefficient of output-labor elasticity above that of the national average, namely :Agriculture (1.987609), Manufacturing (1.5368I5), Trade, Hotel and Restaurant (I.246332), Transportation and Communication (I.334240) and Services (I.53074I). Four sectors with the coefficients of output-capital elasticity below that at the national level, namely : Mining and Quarying (-0.007/85), Electricity, Gas and Drinking Water (-2.69/094), Construction (0.022766), and Financial, rental and Corporate Service (-0.102564).

Table 2 presents the Quadrant of Technical Efficiency (Above Versus Below National Average) and Return to Scale (Increasing Versus Decreasing Return to Scale). Four sectors in which the coefficients of technical efficiency were above that at national level also exhibiting decreasing return to scale. Those sectors were: Mining and Quarrying, Manufacturing, Electricity, Gas and Drinking Water and Construction. Other five sectors in which the coefficients of technical efficiency were below that at national level exhibiting increasing return to scale. Those sectors were: Financial, Rental and Corporate Services, Services, Agriculture, Transportation and Communication, and Trade, Hotel and Restaurant.

Table 2. The Quadrant of Technical Efficiency and Return to Scale

\begin{tabular}{lll}
\hline $\begin{array}{l}\text { Technical Efficiencyl } \\
\text { Return to Scale }\end{array}$ & \multicolumn{1}{c}{$\begin{array}{c}\text { Increasing Return } \\
\text { to Scale }\end{array}$} & $\begin{array}{c}\text { Decreasing Return } \\
\text { to Scale }\end{array}$ \\
\hline Above National Average & \multicolumn{1}{c}{$\begin{array}{c}\text { Mining and Quarrying } \\
\text { Manufacturing } \\
\text { Electricity, Gas and } \\
\text { Drinking Water } \\
\text { Construction }\end{array}$} \\
Below National Average & $\begin{array}{l}\text { Financial, Rental and } \\
\text { Corporate Services } \\
\text { Services }\end{array}$ & \\
& $\begin{array}{l}\text { Agriculture } \\
\text { Transportation and } \\
\text { Communication }\end{array}$ & \\
& Trade, Hotel and & \\
Restaurant & \\
\hline
\end{tabular}

\section{CONCLUSION}

Sectorally, there were 4 sectors that had coefficient of technical efficiency above of that at national level, namely : Electricity, Gas and Drinking Water, Mining and Quarying, Construction, and Manufacturing.These were the sectors that experienced 
decreasing return to scale. Other five sectors that had the coefficient of technical efficiency below of that at the national level, namely : Financial, Rental and Corporate Services, Agriculture, Services, Trade, Hotel and Restaurant and Transportation and Communication. These were the sectors that had experienced increasing return to scale. There was an inverse relationship between technical efficiency and return to scale.

\section{REFERENCES}

Adams, J. (2006).The Contribution of Science and Technology to Production.Cambridge Massachusett: the National Bureau of Economic Research.

Anonymous.(1998; 2004; 2010).National Product Domestic Bruto.Jakarta: National Statistics Agency

Bao Hong, T.(2008), Cobb-Douglas Production Function. retrive on 22 June 2016 from http://docentes.fe.unl.pt/jamador/Macro/cobb-douglas.pdf

Biresh K.S.et.al. (2014).Decomposing technical efficiency and scale elasticity in twostage network DEA. European Journal of Operational Research, Volume 233, Issue 3, pp. 584-594.

Cobb C.W\&P.H. Douglas. (1928). A Theory of Production. American Economic Review.Vol. 18, pp.139-165.

Comin, D. (2006).Total Factor Productivity.New York:New York University.

Erkoc, T.E. (20I2) Estimation Methodology of Economic Efficiency: Stochastic Frontier Analysis versus Data Envelopment Analysis.International Journal of Academic Research in Economics and Management Sciences. Vol. I (I), PP. I-23.

Feng, G \&A. Serletis. (2010)Efficiency, Technical Change, and Returns to Scale in Large US Banks: Panel Data Evidence from an Output Distance Function Satisfying Theoretical Regularity. Journal of Banking \& Finance.Vol 34 (I),pp. I27-I 38.

Gaspersz. V. (1996). Ekonomi Manajerial, Penerapan Konsep-Konsep Ekonomi DalamManajemen Bisnis Total. Jakarta : PT Gramedia Pustaka Utama.

Gebreselasie, T.G. (2008). Sectoral Elasticity of Substitution and Returns to Scale in South Africa.South African Journal of Economics. Special Issue: Industrial growth and employment in South Africa. Volume 76, pp. SII0-SI 25. 
Holyk, S. (2016). Measuring Technical Efficiency and Economy on Scale in Finnish Food Processing Industry.International Journal of Science: Basic and Applied Research.Vol 27, No 3, pp. $211-220$.

Krivonozhko, V. E. et.al. (2007). Computation of elasticity and scale effect in technical efficiency analysis of complex systems. Computational Mathematics and Modeling.Volume 18 (4), pp 432-452.

Page, J. M. Jr. (1980)Technical Efficiency and Economic Performance: Some Evidence from Ghana.Oxford Economic Papers, New Series, Vol. 32(2), pp. 319-339.

Salvator, D.(1996). Managerial Economic in a Global Economy.Boston: Irwin McGraw Hill.

Yudistira, D. (2004).Efficiency in Islamic Banking: An Empirical Analysis of Eighteen Banks.Islamic Economic Studies. Vol. 12 (I), Pp. I-I9. 